\section{Nauplius}

The Journal OF The Brazilian Crustacean Society
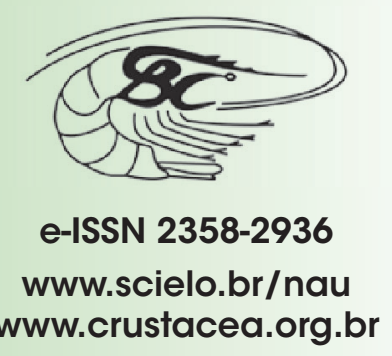

\title{
Extreme morphologies of mantis shrimp larvae
}

\author{
Carolin Haug ${ }^{1}$, Shane T. Ahyong ${ }^{2}$, Joris H. Wiethase ${ }^{3}$, Jørgen \\ Olesen $^{4}$ and Joachim T. Haug ${ }^{1}$
}
1 LMU Munich, Biocenter, Department of Biology II and GeoBio-Center, Großhaderner Str. 2, 82152 Planegg-Martinsried, Germany.
2 Australian Museum, 1 William Street, Sydney, NSW 2010, Australia, and School of Biological, Earth and Environmental Sciences, University of New South Wales, Kensington, NSW 2052, Australia.

3 University of Glasgow, College of Medical, Veterinary and Life Sciences, Graham Kerr Building, Glasgow G12 8QQ, United Kingdom.

4 Natural History Museum of Denmark (Zoological Museum), University of
Copenhagen, Universitetsparken 15, DK-2100 Copenhagen Ø, Denmark.

ZOOBANK http://zoobank.org/urn:lsid:zoobank.org:pub:FCDD50C0-5EB8-4D37B23E-B13148E9FB0E

\begin{abstract}
Larvae of stomatopods (mantis shrimps) are generally categorized into four larval types: antizoea, pseudozoea (both representing early larval stages), alima and erichthus (the latter two representing later larval stages). These categories, however, do not reflect the existing morphological diversity of stomatopod larvae, which is largely unstudied. We describe here four previously unknown larval types with extreme morphologies. All specimens were found in the collections of the Zoological Museum, University of Copenhagen and were collected during the Danish Dana Expedition round the world 1928-30. These new larval types all represent erichthus-type larvae, especially differing in their shield morphologies. The shield morphology ranges from almost spherical to rather disc-like, with sometimes extremely elongated spines, but only a general systematic assignment of the larvae was possible. Further investigations of these larvae are crucial to understand their life habits and ecological impact, especially as stomatopod and other crustacean larvae might have a much more important position in the marine ecosystems than their corresponding adults.
\end{abstract}

\section{KEY WORDS}

Stomatopoda, crustacean larvae, morphological diversity, functional morphology, museum collections.

CORRESPONDING AUTHOR

Carolin Haug

carolin.haug@palaeo-evo-devo.info

SUBMITTED 30 March 2016

ACCEPTED 4 August 2016

PUBLISHED 21 November 2016

DOI 10.1590/2358-2936e2016020 


\section{INTRODUCTION}

Among crustacean larvae, those of mantis shrimps (Stomatopoda) can be considered to be the most aberrant, rivaled perhaps only by those of achelatan (spiny lobsters and slipper lobsters; e.g. Lewis, 1951; Johnson, 1971; Palero et al., 2014) or polychelid decapods (Williamson and Rice, 1996; Martin, 2014; Torres et al.,2014; Eiler et al.,2016) or also the slightly smaller larva formerly known as "Cerataspis monstrosa" (aristeid shrimp; Bracken-Grissom et al., 2012). Four types of mantis shrimp larvae have generally been distinguished, two early larval types and two later larval types (Fig. 1; e.g. Claus, 1871; Giesbrecht, 1910). The early larval stages are called antizoea and pseudozoea (Giesbrecht, 1910). Both forms possess a relatively large shield, which is quite flat and is at least equipped with a long rostrum anteriorly and two long spines postero-laterally. Additional smaller spines are often also present. As far as is known, their body already has the full number of segments developed at hatching, yet the degree of differentiation differs between antizoea and pseudozoea (e.g. Giesbrecht, 1910; Gurney, 1942; 1946).

In an antizoea, the eyes are sessile, the antennulae uniflagellate, and the anterior five pairs of thoracopods are initially biramous and unspecialized, being not yet differentiated as grooming, raptorial and foodprocessing appendages. In a pseudozoea, the eyes are pedunculate, the antennulae biflagellate, and only the anterior two pairs of thoracopods are developed. The first pair already appears strongly elongated, although not yet fully functional, as it is still too short to reach, e.g. the eyes. The second pair of thoracopods, in particular, is well developed, already forming a fully functional uniramous sub-chelate raptorial appendage. The thoracopods $3-5$ are not yet present in the very first stages and appear in later stages of the pseudozoea as small buds. The pleopods especially of the pseudozoea are already quite large, biramous appendages capable of propelling the animal, yet appear to lack the bushy gills of the later developmental stages. A pseudozoea develops either into an erichthus or an alima; an antizoea develops into an erichthus (Ahyong et al., 2014 and references therein).

The erichthus and alima larvae are quite unusual. They reach astonishing sizes for planktic crustacean larvae, measuring up to several centimeters (e.g.
Giesbrecht, 1910; Alikunhi, 1944; Townsley, 1953; Shanbhogue, 1975; Gamô, 1979; Hamano and Matsuura, 1987; Ahyong et al., 2014); larger larval stages are only found among achelatan decapods (phyllosoma larvae) and polychelidan decapods (eryoneicus larvae) (e.g. Johnson, 1971; Martin, 2014; Palero et al., 2014).

All appendages, besides thoracopods 3-5, are already relatively well developed in early erichthus and alima stages; in later stages of these phases, all the appendages have almost reached their final morphology (e.g. Manning and Provenzano, 1963; Pyne, 1972; Provenzano and Manning, 1978; Hamano and Matsuura, 1987). The head shield is quite large in both alima and erichthus. In erichthus larvae the shield often appears more domed and bulging. In alima larvae the shield can also be slightly domed, but more often it appears flat and usually elongated, so that the sensorial structures (eyes, antennulae and antennae) lie much further anteriorly than the mouthparts. Alima and erichthus larvae can be clearly distinguished from each other on the basis of the number of intermediate denticles of the telson ( $1-3$ in erichthus, $4+$ in alima) (e.g. Brooks, 1886; Giesbrecht, 1910; Hansen, 1926; Foxon, 1932; Townsley, 1953) and the position of the eyes. In alima larvae the stalked eyes arise from a bar-like structure. The bar-like structure is absent in erichthus larvae (recent overview in Ahyong et al., 2014). The morphological diversity of stomatopod larvae has been documented in various "classical" studies (Claus, 1871; Giesbrecht, 1910) and in a few more recent ones (Barber and Boyce, 2006; Tang, 2009). Despite some important classical studies, mantis shrimp larvae must be considered to be severely understudied. Almost 500 formally described extant mantis shrimp species are known, but the ontogenetic sequences of only a handful of species are available (Gohar and AlKholy, 1957; Manning and Provenzano, 1963; Pyne, 1972; Provenzano and Manning, 1978; Morgan and Provenzano, 1979; Greenwood and Williams, 1984; Hamano and Matsuura, 1987; Morgan and Goy, 1987; Diaz and Manning, 1998; see discussion in Haug et al., 2016). Larval specimens from plankton samples can often only be identified to higher taxonomic units (examples in Shanbhogue, 1975; Brandão et al., 2015; for a counterexample, see Veena and Kaladharan, 2010). Newer advances in DNA fingerprinting offer promising 


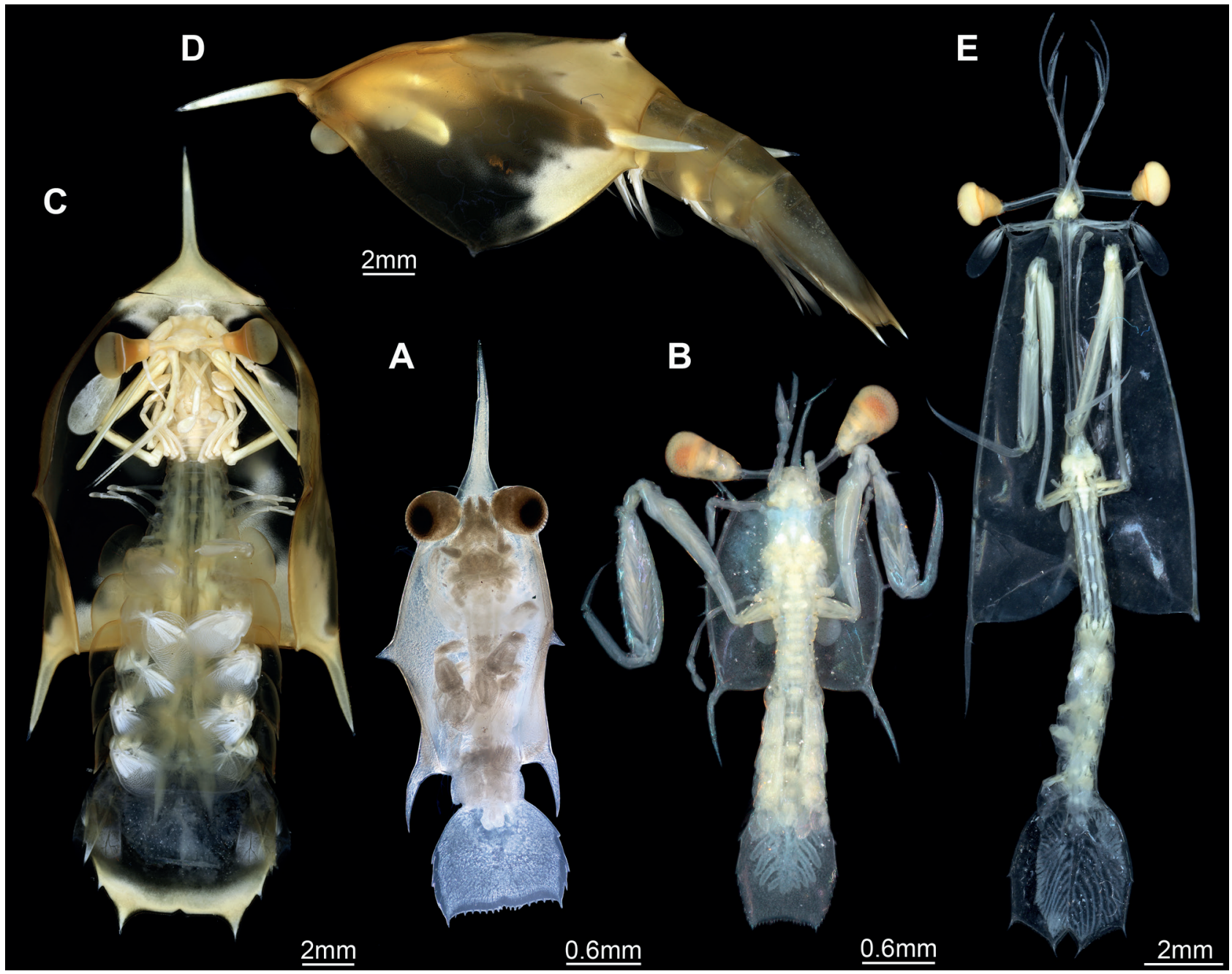

Figure 1. The four common types of mantis shrimp larvae. A. Antizoea, late form; ZMUC-CRU-8654. B. Pseudozoea; ZMUCCRU-8659. C, D. Erichthus; ZMUC-CRU-8660. E. Alima, flipped horizontally; ZMUC-CRU-8655. A-C, E. Ventral view. D. Lateral view. A. Transmitted light. B-E. Reflected light.

results (Feller et al., 2013), but also indicate that the true diversity of mantis shrimps is underestimated (Barber and Boyce, 2006; Tang et al., 2010).

We report here new, previously unknown forms of mantis shrimp larvae. The specimens were collected during the Danish Dana expedition in 1928-30, and significantly enlarge the known morphological diversity of planktic crustacean larvae.

\section{Material and Methods}

\section{Material}

All larval mantis shrimp specimens described and depicted here are part of the collection of the Zoological Museum, University of Copenhagen (ZMUC; Tab. 1). They were collected during the Danish Dana Expedition round the World 1928-30. The specimens stem exclusively from plankton samples. All specimens are stored in $70 \%$ ethanol but they were originally fixed in formaldehyde.

\section{Documentation methods}

All specimens were documented directly in $70 \%$ ethanol, which was their storage liquid. As some of the specimens were flexible to a certain degree, it was possible to carefully outstretch and secure them under a cover slip. Larger specimens were fixed using two cover slips, one anteriorly and another posteriorly. For images in other orientations (lateral, anterior, posterior), specimens were propped against either glass or metal objects.

All specimens were photographed with a Canon Rebel T3i digital camera and a Canon MP-E $65 \mathrm{~mm}$ macro lens. Illumination was either provided by a Canon Macro Twin Flash MT 24-EX or a MeiKe FC 
Table 1. Original localities of the specimens, all from pelagic samples, and additional data from the "Dana" II expedition (1928-30).

\begin{tabular}{|c|c|c|c|c|c|c|c|}
\hline Registration number & Larval type & $\begin{array}{l}\text { Station } \\
\text { number }\end{array}$ & Region & Locality & Lat/Long & Depth & Date \\
\hline ZMUC-CRU-8654 & late antizoea & $3567-2$ & Central Pacific & Marquesas Is.-Tahiti & $09^{\circ} 06^{\prime} \mathrm{S} 140^{\circ} 21.5^{\prime} \mathrm{W}$ & $2840 \mathrm{~m}$ & $\begin{array}{c}\text { October 4, } \\
1928\end{array}$ \\
\hline ZMUC-CRU-8655 & alima & $3689-9$ & Central Indo-Pacific & South China Sea & $07^{\circ} 13.5^{\prime} \mathrm{N} 111^{\circ} 49^{\prime} \mathrm{E}$ & $1975 \mathrm{~m}$ & $\begin{array}{l}\text { April 9, } \\
1929\end{array}$ \\
\hline ZMUC-CRU-8659 & pseudozoea & $3723-5$ & Central Indo-Pacific & East China Sea & $25^{\circ} 30.5^{\prime} \mathrm{N} 125^{\circ} 28^{\prime} \mathrm{E}$ & $1520 \mathrm{~m}$ & $\begin{array}{c}\text { May 30, } \\
1928\end{array}$ \\
\hline ZMUC-CRU-8660 & erichthus & $3748-2$ & Central Indo-Pacific & N of NW New Guinea & $03^{\circ} 48^{\prime} \mathrm{N} 133^{\circ} 35^{\prime} \mathrm{E}$ & $3070 \mathrm{~m}$ & $\begin{array}{c}\text { July 10, } \\
1929\end{array}$ \\
\hline ZMUC-CRU-8661 & gnome hat & $3766-20$ & Central Indo-Pacific & N of NW New Guinea & $01^{\circ} 13^{\prime} \mathrm{S} 138^{\circ} 42^{\prime} \mathrm{E}$ & $2825 \mathrm{~m}$ & $\begin{array}{c}\text { July 23, } \\
1929\end{array}$ \\
\hline ZMUC-CRU-8662 & smaller balloon-larva & $3768-15$ & Central Indo-Pacific & N of NW New Guinea & $01^{\circ} 20^{\prime} \mathrm{S} 138^{\circ} 42^{\prime} \mathrm{E}$ & $3450 \mathrm{~m}$ & $\begin{array}{c}\text { July 25, } \\
1929\end{array}$ \\
\hline ZMUC-CRU-8663 & larger balloon-larva & $3768-18$ & Central Indo-Pacific & N of NW New Guinea & $01^{\circ} 20^{\prime} \mathrm{S} 138^{\circ} 42^{\prime} \mathrm{E}$ & $3450 \mathrm{~m}$ & $\begin{array}{c}\text { July 25, } \\
1929\end{array}$ \\
\hline ZMUC-CRU-8664 & erichthus & $3954-5$ & Western Indian Ocean & $\begin{array}{c}\text { Mombasa-Moçambique } \\
\text { Channel }\end{array}$ & $16^{\circ} 53^{\prime} \mathrm{S} 042^{\circ} 12^{\prime} \mathrm{E}$ & $2250 \mathrm{~m}$ & $\begin{array}{c}\text { January 9, } \\
1930\end{array}$ \\
\hline ZMUC-CRU-8665 & spiny balloon & $3956-1$ & Western Indian Ocean & $\begin{array}{c}\text { Mombasa-Moçambique } \\
\text { Channel }\end{array}$ & $21^{\circ} 13^{\prime} \mathrm{S} 042^{\circ} 26^{\prime} \mathrm{E}$ & $2350 \mathrm{~m}$ & $\begin{array}{c}\text { January 10, } \\
1930\end{array}$ \\
\hline ZMUC-CRU-8666 & flying saucer & $3957-4$ & Western Indian Ocean & $\begin{array}{c}\text { Mombasa-Moçambique } \\
\text { Channel }\end{array}$ & $21^{\circ} 30^{\prime} \mathrm{S} 042^{\circ} 32^{\prime} \mathrm{E}$ & $2350 \mathrm{~m}$ & $\begin{array}{c}\text { January 11, } \\
1930\end{array}$ \\
\hline ZMUC-CRU-8667 & erichthus & $3957-4$ & Western Indian Ocean & $\begin{array}{c}\text { Mombasa-Moçambique } \\
\text { Channel }\end{array}$ & $21^{\circ} 30^{\prime} \mathrm{S} 042^{\circ} 32^{\prime} \mathrm{E}$ & $2350 \mathrm{~m}$ & $\begin{array}{c}\text { January 11, } \\
1930\end{array}$ \\
\hline ZMUC-CRU-8668 & erichthus & $3958-2$ & Western Indian Ocean & $\begin{array}{c}\text { Mombasa-Moçambique } \\
\text { Channel }\end{array}$ & $23^{\circ} 11^{\prime} \mathrm{S} 042^{\circ} 54^{\prime} \mathrm{E}$ & $3100 \mathrm{~m}$ & $\begin{array}{c}\text { January 11, } \\
1930\end{array}$ \\
\hline
\end{tabular}

100 LED ring light. In both cases light sources were equipped with polarisation filters and a perpendicular oriented filter was placed in front of the lens. This crosspolarised light set-up significantly reduces reflections, which is especially important for photographing specimens immersed in liquid (e.g. Haug et al., 2011 and references therein). Additionally, the color contrast is enhanced with such a set-up, because at higher magnifications, colors often appear "washed out", an effect most likely caused by internal reflections.

To compensate for the limited depth of field at higher magnifications, we recorded stacks of images, each image (frame) in a different focal plane. These image stacks were fused to sharp images in the software CombineZM/ZP or Image Analyzer. To compensate for limitations of field of view at higher magnifications, we recorded several adjacent image details (each one with a stack). Fused images for each image detail were then stitched together to form a single large image (panorama) in Microsoft Image Composite Editor or with the photomerge function of Adobe Photoshop CS3 (Haug et al., 2009; 2011). Further processing of the images was performed in Adobe Photoshop CS3 or CS6, and included global and local optimizations of histograms, saturation, sharpness (mask unsharp filter) and manual cleaning of the background.

To better document the three-dimensional shape of the specimens, some were additionally documented as stereo images by photographing them from different viewing angles (Haug et al., 2011). Such half images were processed into red-cyan anaglyphs in Adobe Photoshop CS3 or CS6.

\section{Taxonomic treatment}

As stated above, currently, the identification of stomatopod larvae to specific species is challenging to impossible. We therefore refer only to morphotypes in the Results and Discussion. As the discussion will concentrate on morphological diversity rather than on species diversity, this should not be disadvantageous. To allow later reference, each morphotype is given a descriptive name.

\section{Terminology}

To allow a larger readership to follow the descriptions in this paper and to avoid the use of debatable homology assumptions, the applied terminology in the following will be kept in relatively neutral arthropod terms 
where possible without losing clarity (see e.g. Haug et al., 2012). For example, "shield" is used instead of "carapace", as the first term is more general and the latter has been applied very differently, but "pleon" is used instead of "abdomen", as it is a more precise term for eumalacostracan crustaceans.

\section{ResULTS}

From the collection of stomatopod larvae of the Zoological Museum, University Copenhagen a number of different morphotypes are described. Four of these are new to science; other morphotypes shown here have been reported before, but are shown here for comparison.

\section{General description}

All specimens are large and well developed. They are identified as erichthus-type larvae, based on their general habitus, the shorter "eye stalks", and only one or two intermediate denticles on the telson.

All appendages, as far as observable, are at an advanced stage of development (in morphotype 4 (see below) most appendages are concealed due to its enrolled posture). The flagella of the antennula and antenna appear to be already subdivided into numerous elements, while in early larvae only the distal parts are subdivided. The posterior thoracopods 5-8 are already differentiated, although they still appear somewhat short; in earlier stages these appendages usually lack subdivision. Pleopods already bear gills on the exopods, while earlier larvae in general lack these. Uropods are well-developed; the exopod bears movable spines along its lateral margin; its distal article is already demarcated. In younger larvae, spines and the distal article are still conjoined with the proximal exopod element.

The different specimens mainly differ through the aberrant-appearing morphologies of their shields. Hence, these are the focus of the descriptions of the morphotypes.

\section{Morphotype 1: "Balloon-larva"}

Two specimens of this morphotype have been found (ZMUC-CRU-8662, ZMUC-CRU-8663; Figs. 2, 3 ). The specimens have the quadrate propodi (in anterior view) with ventral ribbing of the maxillipeds 3 and 4 indicating that these are lysiosquilloid or erythrosquilloid larvae.
The shield is huge, enclosing almost the entire body. It is almost circular in outline in dorsal or ventral view (Figs. 2A, B, E, 3A, B). In frontal or posterior view, the general outline could also be described as circular, but with a distinct notch ventrally (Figs. $2 \mathrm{D}, 3 \mathrm{D}, \mathrm{E})$. In lateral view, the outline of the shield is subquadrate (Figs. 2C,3C). In overall appearance the shield is strongly inflated and somewhat reminiscent of a balloon. A distinct, thin ridge defines the lateral margins of the shield, extending from the base of the rostral spine, where the ridge is less defined, posteriorly to the base of the posterolateral spines (Figs. 2C, 3C); their apices are inclined postero-ventrally. In posterior view another pair of marginal ridges is apparent, also continuing into these spines (Figs. 2D, 3E). These edges surround the notch, i.e. the posterior "opening" of the shield, at a slight distance from the actual rim. Hence, these two unite above the notch where another strong spine is present, pointing postero-dorsally. Another edge connects this spine and the rostrum.

The raptorial claws in particular show important differences from those of the other morphotypes. The dactylus and propodus, the two most distal elements forming the actual claw, are very slender and straight. The propodus carries a single small spine medially, at about two-fifths towards the distal end. The dactylus is devoid of any spines and straight except for slight distal curvature.

The tergite of pleomere 6 bears a pair of small submedian spines on the posterior margin and a small postero-lateral spine. The telson armature is also different between the different morphotypes described herein; this type has 18 pairs of submedian denticles, two intermediate denticles and one lateral denticle.

The two specimens of the "balloon-larva" clearly represent two different size classes. The smaller specimen is about $13 \mathrm{~mm}$ long (excluding the spines) and about $16 \mathrm{~mm}$ wide. The larger specimen is about $17 \mathrm{~mm}$ long (excluding spines) and about $20 \mathrm{~mm}$ wide. With a difference in size of approximately $30 \%$, we surmise that the two specimens might well represent two successive stages of the same species (or closely related species). The larger specimen is less well preserved, with several fractures in the shield due to compression. Therefore, only the smaller, better preserved specimen was documented more intensively. As both did not differ significantly in their general 


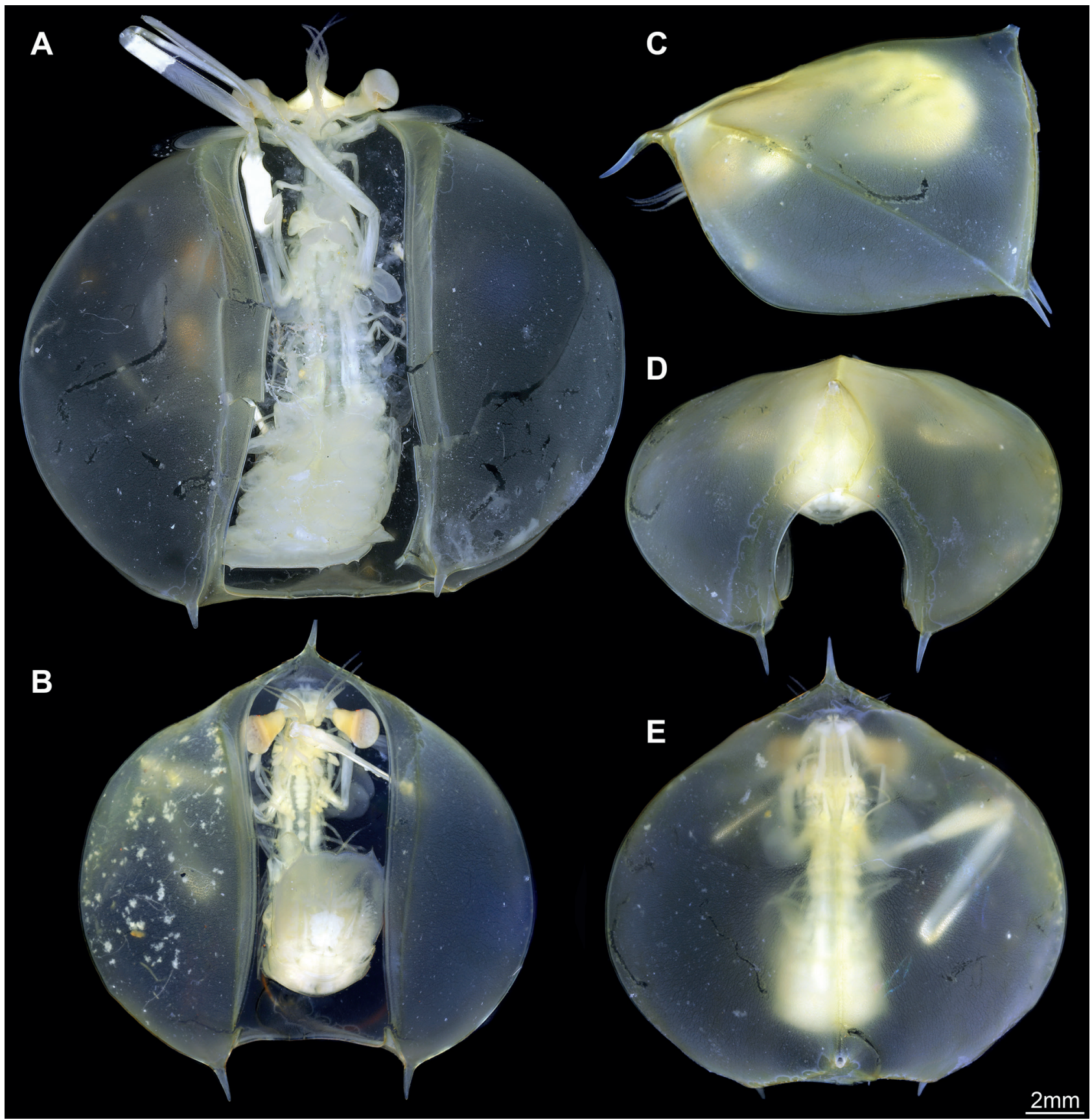

Figure 2. New morphotype 1, "balloon-larva”. A. ZMUC-CRU-8663, larger specimen; note the damaged shield. B-E. ZMUCCRU-8662, smaller specimen. A, B. Ventral view. C. Lateral view; note the pronounced edge from the rostrum to the postero-lateral spine. D. Posterior view. E. Dorsal view.

morphology, this was seen as the best strategy to preserve the larger specimen without further damaging it.

The dorsal outline of the shield of a lysiosquilloid larva reported by Michel (1968) as "Lysiosquilla sp. B." is more or less similar to the "balloon-larva", though it is less inflated dorsally and ventrally in "Lysiosquilla sp. B..

Morphotype 2: "Gideon's larva 1 - spiny balloon"
A single specimen of this morphotype (ZMUCCRU-8665; Fig. 4) was found in the collection by Gideon T. Haug, Neuried. Like the "balloon-larva", the morphotype 2 specimen or "spiny balloon" has the quadrate propodi (anterior view) with ventral ribbing of the maxillipeds 3 and 4, indicating that it is a lysiosquilloid or erythrosquilloid larva. The flattened uropodal basipodal spines suggest that this form may represent a species within Tetrasquillidae. 

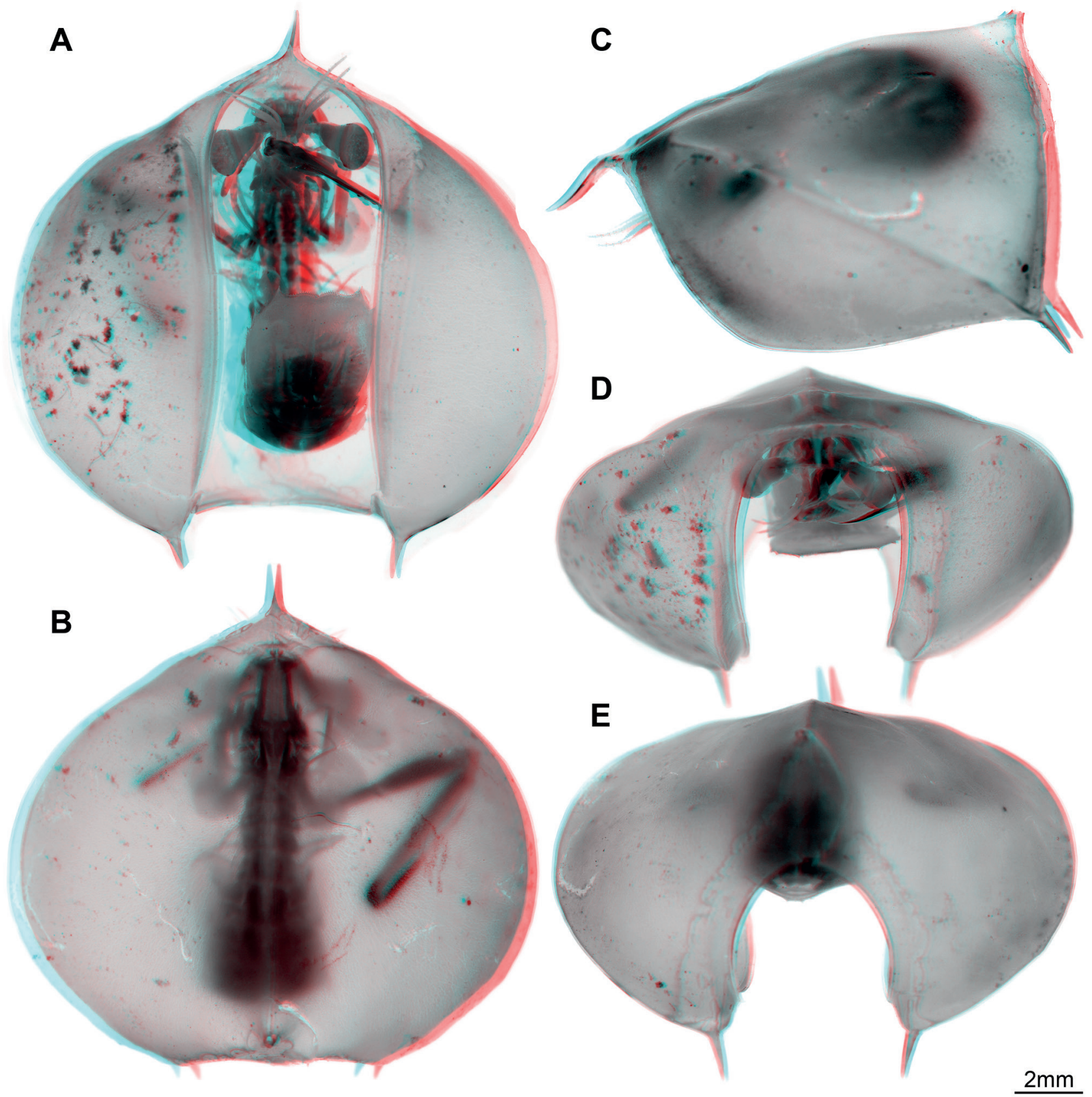

Figure 3. Red-cyan stereo-anaglyph images of ZMUC-CRU-8662; smaller specimen of “balloon-larva”. Please use red-cyan glasses to view, red left, cyan right. A. Ventral view. B. Dorsal view. C. Lateral view. D. Frontal view. E. Posterior view. All images inverted for enhancing contrast.

The specimen measures about $18 \mathrm{~mm}$ in length, excluding the long spines. The shield is comparable in ventral view to the "balloon-larva". Yet, the outline is not sub-circular but more cordiform, forming a tip anteriorly (Fig. 4A, B). Also apparent in ventral view, the postero-lateral spines are significantly longer than the rostral spine. Another difference recognizable in ventral view is that the ventral gape is less constricted than in the "balloon-larva". In lateral or anterior view it becomes obvious that the shield is more streamlined, i.e. at least 1.5 times as long as high. As in other larvae, a thin lateral ridge runs from the base of the rostrum posteriorly to the base of the postero-lateral spines, but the edges surrounding the posterior gape appear to fade out towards the dorsal and do not reach the posterodorsal spine (Fig. 4D). The lateral outline, however, is more triangular than quadrate. An additional low ridge appears to connect the rim of the posterior gape and the postero-dorsal spine. 


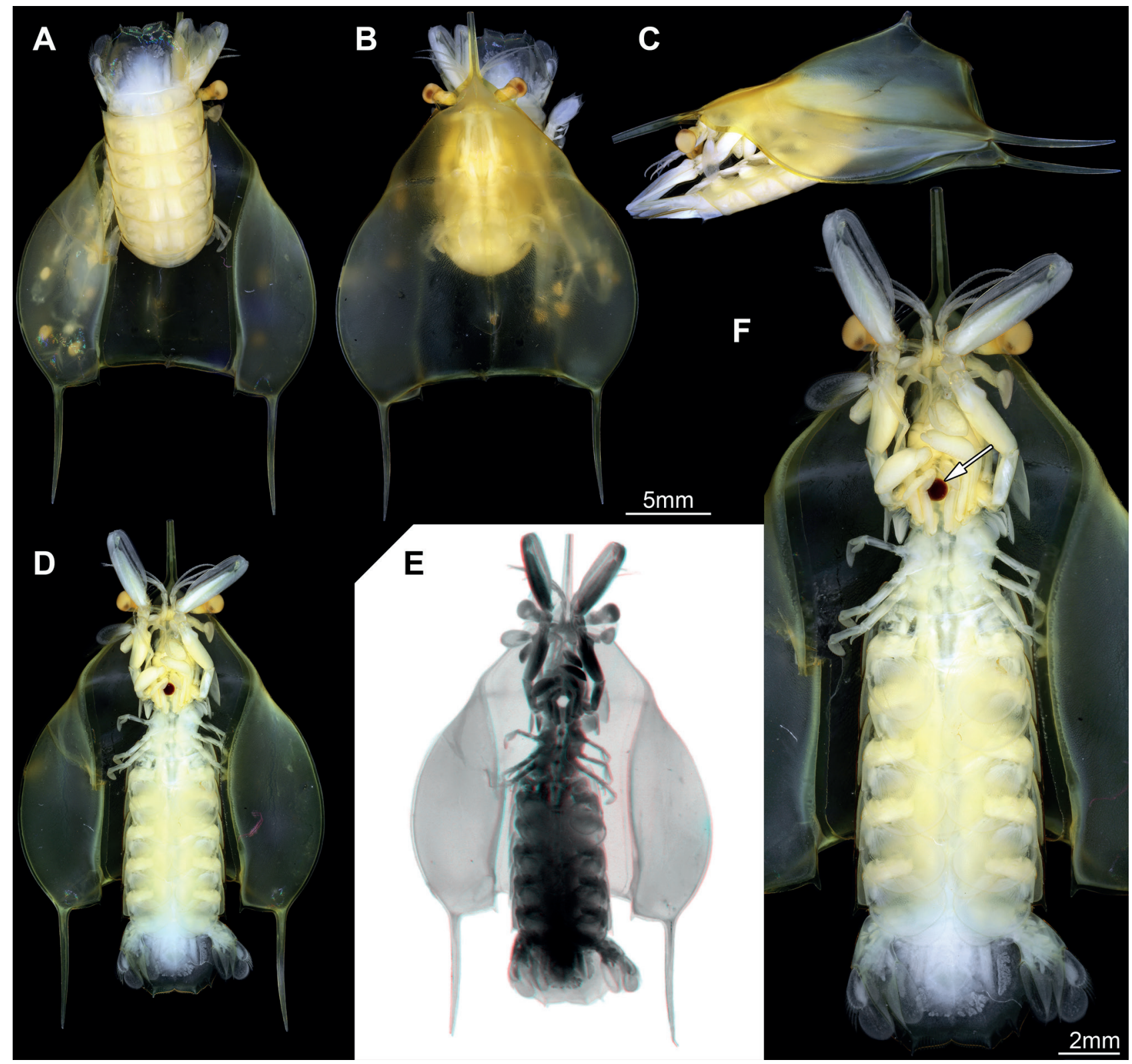

Figure 4. New morphotype 2, "spiny balloon”; ZMUC-CRU-8665. A-C. Original condition as found in the jar; the pleon is bend far anteriorly within the "pockets" of the shield several small alima larvae are trapped. A. Ventral view. B. Dorsal view. C. Lateral view. D-E. Repositioned, alima larvae removed; ventral view. D. Overview. E. Red-cyan stereo-anaglyph image. F. Close up on central body region. Arrow marks possible acanthocephalan.

In contrast to the "balloon-larva", the raptorial claw is less slender. The propodus is more massive with a medio-proximal spine. The dactylus tapers distally and is inwardly curved, resulting in a scimitar-like shape.

The tergite of pleomere 6 bears a pair of small submedian spines and larger postero-lateral spines. The telson armature differs from the "balloon-larva", with 14 pairs of submedian denticles, 2 intermediate denticles and 1 lateral denticle.

This specimen demands some comments concerning its preservation. The trunk was strongly flexed forward (as seen in Fig. 4A-C), and two relatively small alimalarva specimens were trapped inside the shield (Fig. 4A, B). These larvae probably became entangled during the process of collection or later during sorting and storage, as numerous specimens were typically stored in a single jar. They were removed carefully. When unfolding the trunk for ventral documentation a prominent red spot became apparent close to the mouthparts (Fig. 4D-F). This possibly represents an acanthocephalan parasite. To our knowledge, acanthocephalans have so far not been reported from stomatopod larvae, but 
are well known from other crustaceans also of smaller sizes, e.g. gammarideans (Crompton and Nickol, 1985; Kennedy, 2006).

\section{Morphotype 3: "Gideon's larva 2 - flying saucer"}

This single specimen (ZMUC-CRU-8666; Figs. 5, $6 \mathrm{~A}-\mathrm{C}$ ) was also found in the collection by Gideon $\mathrm{T}$. Haug, Neuried and represents a gonodactyloid (sensu lato), eurysquilloid, parasquilloid or possibly even a bathysquilloid form, based on the ovate propodi of thoracopods 3 and 4, and the presence of two intermediate denticles on the telson. The specimen is slightly longer than $27 \mathrm{~mm}$ (excluding the spines) and slightly wider than $29 \mathrm{~mm}$. The shield appears even larger than in the preceding morphotypes in dorsal or ventral view (Figs. 5A, B, 6A, B). Its outline is almost circular in dorsal view and the ventral gape is quite wide, even more so than in the "spiny balloon". Most likely functionally coupled to this, the trunk also appears slightly wider; the tergo-pleura are well developed with pronounced spines. In anterior and lateral view the outline of the shield is flatter than in the preceding morphotypes (thus called "flying saucer"; Figs. 5C, D, 6C), but still recognizably triangular as in the "spiny balloon". The shield volume lateral to the body therefore forms almost closed pockets. Also pronounced edges are apparent here, forming the same system as in the "spiny balloon". Especially pronounced are the lateral margins running from the rostrum to the postero-lateral spines. These have the appearance of the edges of a rounded wing. All four spines are proportionally shorter than in the "spiny balloon", and closer to the "balloon-larva". Two additional even smaller spines flank the rostrum.

The raptorial claw appears more massive than in the other morphotypes. The propodus is ovate in anterior view; the median edge is strongly serrated. Proximally, two fixed spines are present, a larger and a smaller one, which would develop into the articulated spines during the transition to post-larva. The dactylus is distinctly curved and scimitar to sickle-shaped.

The tergite of pleomere 6 is armed with small posterolateral spines and a pair of prominent submedian spines on the posterior margin that are considerably longer than in the other morphotypes. The telson is damaged on the right side. It bears 31 or 32 pairs of submedian denticles, and two intermediate denticles and one lateral denticle; the submedian teeth appear to be fixed.

Preservational aspects of the specimen concern post-mortem deformations as well as some which must have occurred during life. The thoracic region appears to have become folded twice in a kind of $\mathrm{z}$-shape, probably due to storage in a small jar. It was difficult to unfold and stabilize this region. Therefore, the specimen appears slightly longer in dorsal view, where it was possible to achieve a more stable fixation, while in ventral and lateral view the thorax is still partly folded. Original damage appears to be present on the distal part of the right uropodal exopod and distal portion of the uropodal protopod. The distal segment is absent of the right side and both primary spines of the right uropodal protopod are absent, probably a result of damage or moult failure.

\section{Morphotype 4: "Gnome hat larva"}

The single specimen (ZMUC-CRU-8661; Figs. 6D-F, 7 ) is about $15 \mathrm{~mm}$ wide and long (excluding spines, only shield). The height is difficult to measure but of about the same dimension. The shield is trapezoidal in dorsal view, but little divergent from a square (Figs. $6 \mathrm{D}, 7 \mathrm{C}$ ). The rostrum is strongly bent downward (Fig. 7B) and a prominent spine is present on each corner of the trapezoid (one on each anterolateral and posterolateral corner). In anterior view the shield is triangular in outline as it is in lateral view ("gnome hat larva”; Figs. 6E, 7A). The same system of edges appears to be present as seen in the other morphotypes. As the main difference, the two spines flanking the rostrum observed in the "flying saucer" are significantly larger and stand further apart. Compared to the "balloonlarva”, the shield appears to be extended posterodorsally, terminating in a strong dorso-median spine. In posterior view, a lateral protrusion on each side of the shield is visible (Figs. 6F, 7D), but not as pronounced as the "pockets" in the "spiny balloon" or the "flying saucer".

The telson armature is more difficult to observe; about 20 pairs of submedian denticles and a single intermediate denticle are present.

This specimen is almost completely enrolled (see Haug and Haug, 2014), hence details of the body are more difficult to observe. The correlation of the ventral gape and the width of the pleomere tergites indicate 


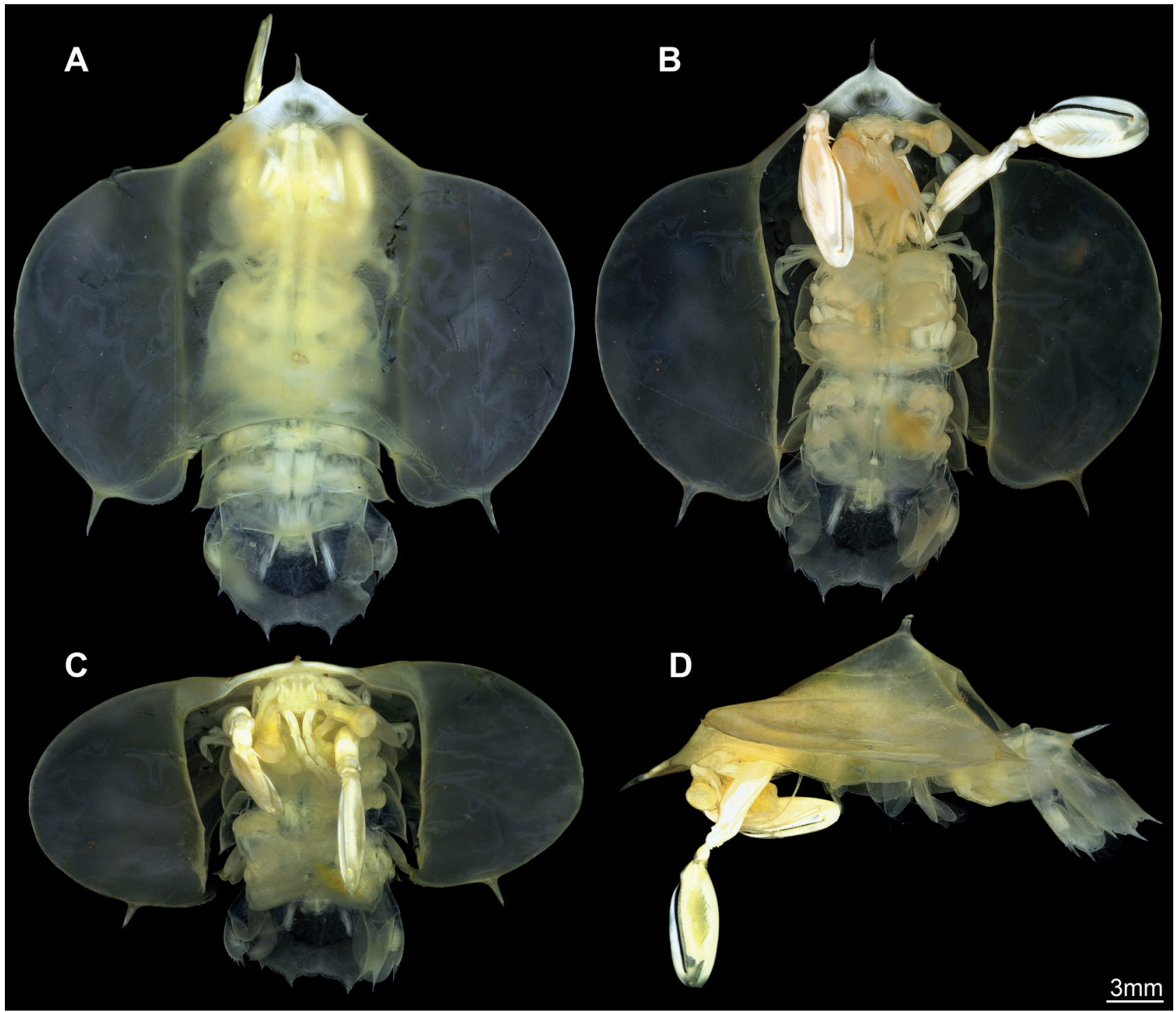

Figure 5. New morphotype 3, "flying saucer"; ZMUC-CRU-8666. A. Dorsal view. B. Ventral view. C. Antero-ventral view. D. Lateral view.

that this larva is fully adapted for defensive enrolling. The massive spines and the enlarged dorsoventral axis most likely are correlated with this.

The overall shield outlines of the gnome hat-larva are similar to that reported for the gonodactyloid Chorisquilla tuberculata (Borradaile, 1907) (Protosquillidae) (Michel and Manning, 1972), albeit more strongly inflated dorsally.

\section{DISCUSSION}

Structural aspects

All four unusual larval morphotypes described here are erichthus-type larvae, as clearly seen by the telson armature. While these larvae indeed appear quite bizarre, they can in fact be easily derived from known erichthus larval forms such as those shown in Fig. 8 by allometric growth of certain regions of the shield. For example, the "gnome hat larva" can be seen as a more extreme version of a more "ordinary" stomatopod larval type (Fig. 8A-D). It shows the same arrangement of spines and also has lateral "pockets". To achieve the arrangement of the "gnome hat larva", only an extrusion in dorso-ventral axis would be necessary.

Another morphotype (Fig. 8E-G) we documented in the ZMUC material appears intermediate in morphology between a "normal" erichthus-type larva and the "spiny balloon" or the "flying saucer": It is flatter, but also has lateral pockets. This morphotype was already described as a giant larva of Lysioerichthus sp. by Gamô (1979) but is smaller than the new 

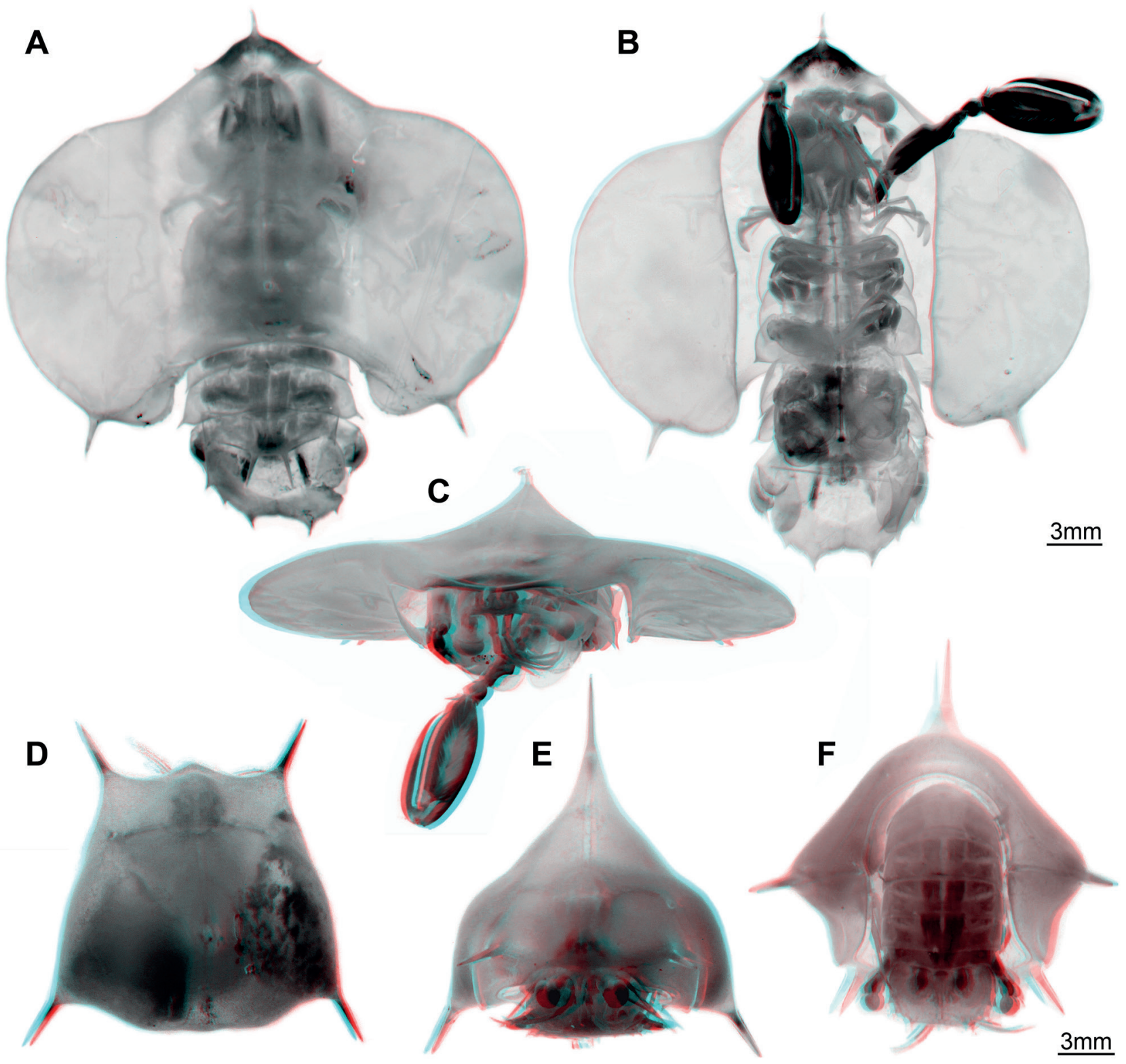

Figure 6. Red-cyan stereo-anaglyph images of the "flying saucer" and the "gnome hat". A-C. "Flying saucer"; ZMUC-CRU-8666. A. Dorsal view. B. Ventral view. C. Anterior view. D-F. “Gnome hat”; ZMUC-CRU-8661. D. Dorsal view. E. Anterior view. F. Posterior view.

morphotypes (roughly similar appearing morphotypes have been figured in Shanbhogue, 1975: fig. 3). Finally, the "balloon-larva" could be derived from a slightly more domed, but comparably pocketed morphotype also found in the ZMUC collections (Fig. 8H-J).

These less aberrant-appearing forms (Fig. 8A-J) not only bridge the morphological strangeness of the new forms; they also might be earlier ontogenetic stages which will develop into the highly specialized new forms, or could represent larval stages of closely related species which lack such extreme adaptations.
Functional morphology and autecology

All aberrant-appearing larval morphotypes reported herein are of a relatively large size. Indeed, they are among the largest dome-shielded stomatopod larvae known so far. Similar-sized or even larger larvae are of the alima-type with an elongated and quite flat shield.

The specific shapes of the shields described herein most likely provide additional buoyancy. Similar bulging shields are also known in another malacostracan group with giant larvae, namely Polychelida (Williamson and Rice, 1996; Martin, 2014; Torres et al., 2014; Eiler et 


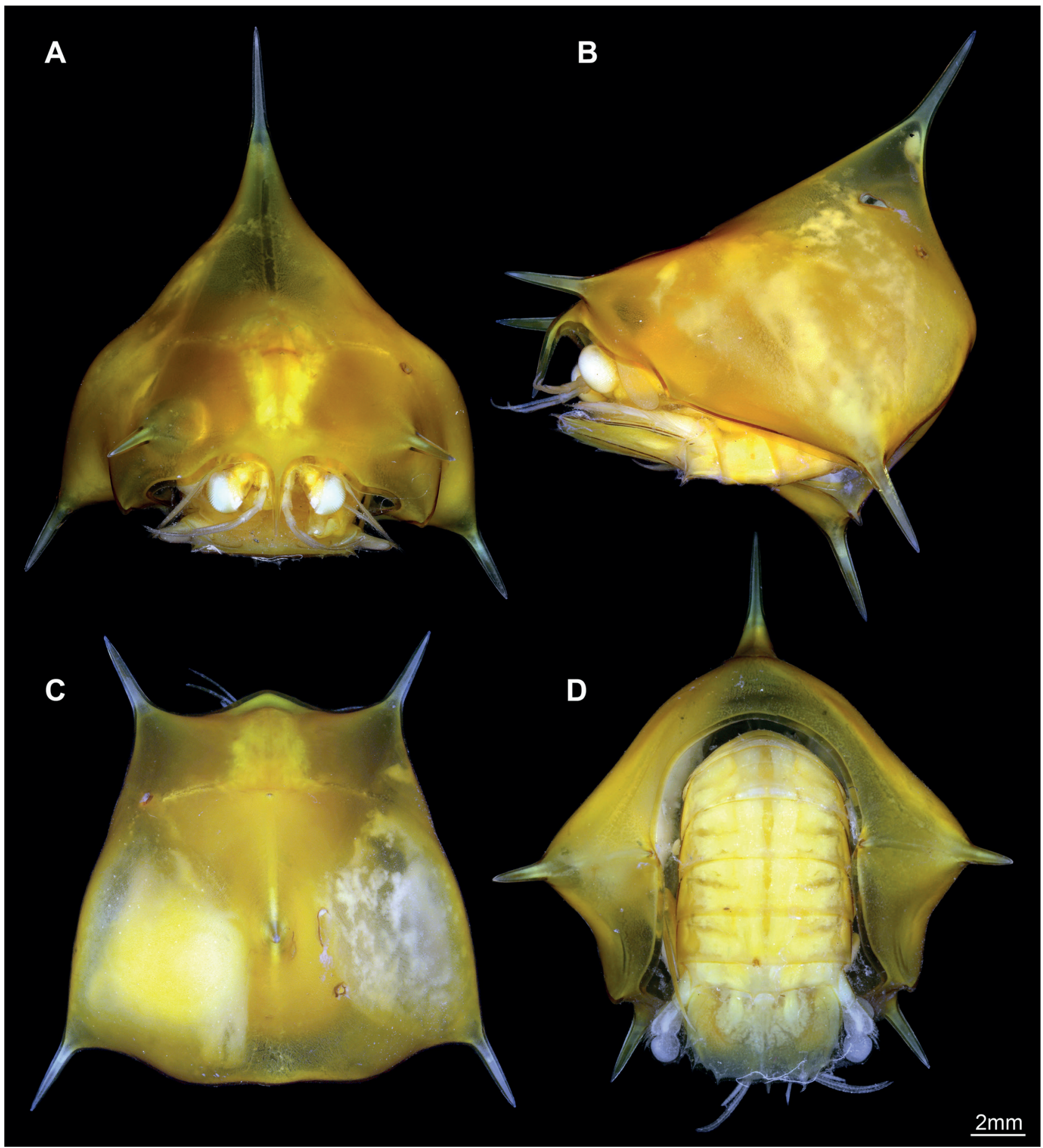

Figure 7. New morphotype 4, "gnome hat"; ZMUC-CRU-8661. A. Anterior view. B. Lateral view. C. Dorsal view. D. Posterior view.

al., 2016). The long spines seen in the "spiny balloon" probably also increase the buoyancy of this larval type. Additionally, they may have defensive function (Haug and Haug, 2014).

Although the pleopods of the here described forms are already well developed, it remains unclear how actively these forms can swim. Especially for the "balloon-larvae", the drag that results from their large shield must be assumed to be comparably high. If so, this form most likely did not actively swim very long distances, but may have been passively transported by ocean currents. For such a morphotype, the general description "floating ambush predator" might be appropriate.

The "spiny balloon" and especially the "flying saucer" appear more streamlined. When viewed anteriorly, the 


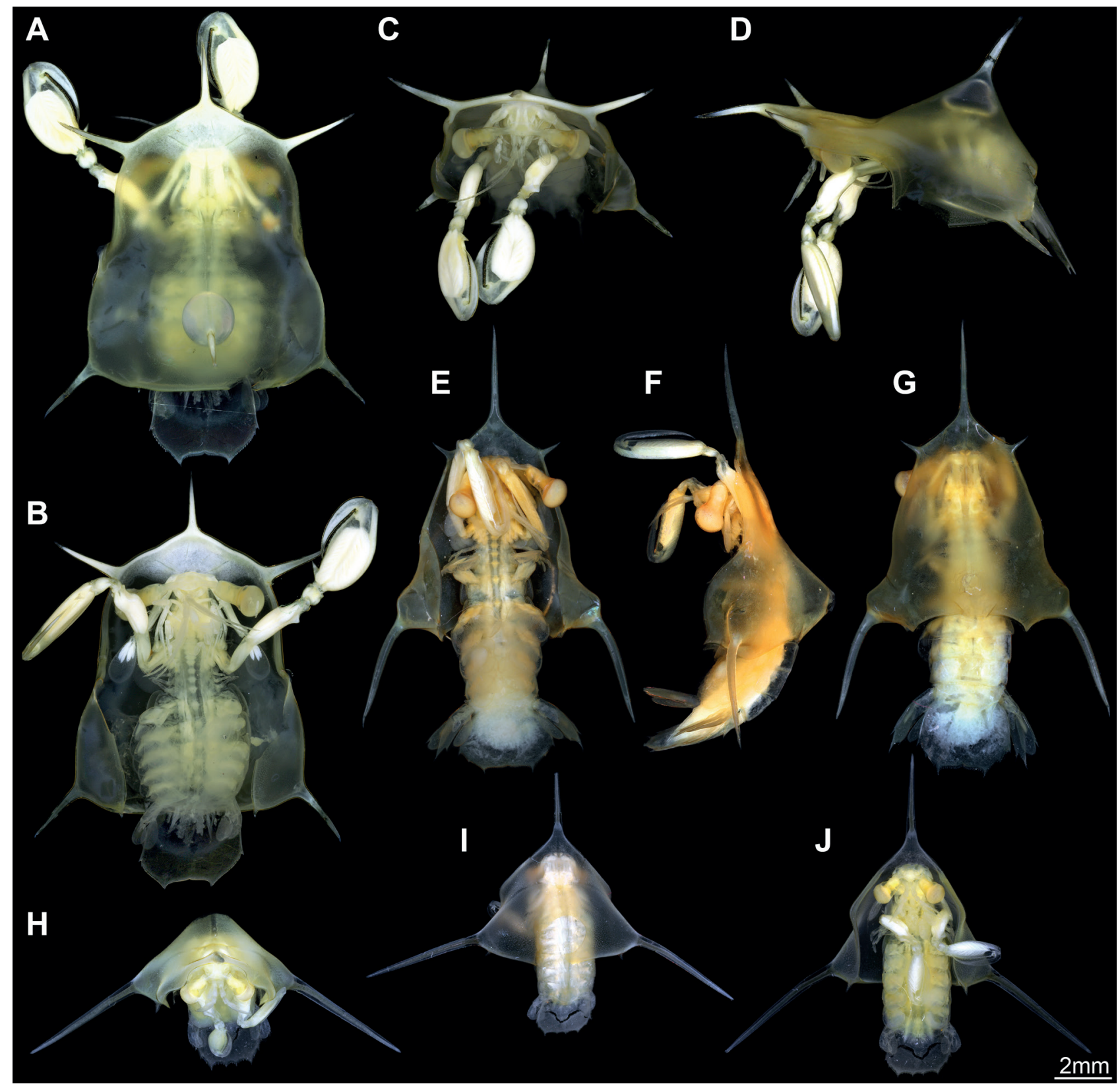

Figure 8. Different erichthus-type larvae demonstrating the morphological diversity. A-D. ZMUC-CRU-8667. A. Dorsal view. B. Ventral view. C. Antero-ventral view. D. Lateral view. C, D flipped horizontally. E-G. ZMUC-CRU-8668. E. Ventral view. F. Lateral view. G. Dorsal view. H-J. ZMUC-CRU-8664. H. Anterior view. I. Postero-dorsal view. J. Ventral view

"flying saucer" almost appears like an airplane with its laterally oriented shield "wings". Thus, these forms, especially the latter, might be more effective swimmers. Still, the buoyancy provided by their large shield must play an important role in their locomotion and for vertical migration in the water column.

Species diversity and morphological diversity

Stomatopod larvae and stomatopod development is a field that is clearly understudied (Ahyong et al., 2014; Haug and Haug, 2014). The fact that the here described types of larvae, which are several centimeters in size, have not been previously recorded emphasizes this point. Additionally, that these specimens remained "undiscovered" in a museum collection for more than 80 years further supports this observation.

The currently known morphological diversity, and also species diversity, of mantis shrimp larvae appears to represent only a part of the true richness of species and forms of this group. DNA-barcoding studies on mantis shrimp larvae have indicated that a significant part of the true diversity of Stomatopoda is still unknown 
(Barber and Boyce, 2006; Tang et al., 2010).

Extensive samples of stomatopod larvae are present in museum collections around the world, such as that of the Zoological Museum, University of Copenhagen. The presence of such a large number of individuals indicates that stomatopod larvae represent an important part of the pelagic ecosystem. As stomatopod larvae grow to astonishing sizes, as in the specimens described, they remain in the pelagic realm for a long time compared to most other crustacean larvae (Ahyong et al., 2014). This suggests that the larval phase of stomatopods represents an ecologically significant part of their life history. Considering the differentiated larval forms, stomatopods may show a greater variety of ecological adaptations in larvae than in adults.

\section{Conclusions}

The importance of biodiversity and evolutionary biology research is well recognized. Most taxonomic research, however, tends to focus on adults. The presence of remarkable larval forms of Stomatopoda, which cannot yet be matched to known adult species, highlights the importance of also including larvae in biodiversity studies. In a modern holistic biology this should be self-evident, yet the present case highlights that much progress remains to be made in documenting and understanding the diversity and ecological importance of stomatopod and other planktic larvae.

\section{ACKNOWLEDGEMENTS}

Tom Schiøtte and Danny Eibye-Jacobsen, Copenhagen are heartily thanked for their help while working in the collection. Special thanks go to Gideon T. Haug, Neuried, who helped intensively during the documentation of the specimens; he also found two of the spectacular specimens. The visit was made possible for $\mathrm{CH}$ by a grant from the European Commission's (FP 6) Integrated Infrastructure Initiative program SYNTHESYS (DK-TAF-2591). Three anonymous reviewers kindly improved the manuscript with their helpful comments. This work is part of JTH's project "Palaeo-Evo-Devo of Malacostraca" kindly funded by the German Research Foundation (DFG) under Ha6300/3-1. We thank all people involved in providing open source, open access or low cost software such as OpenOffice, Combine ZM/ZP, Image Analyzer, Gimp, or Microsoft Image composite editor. This is a contribution from the Australian Museum Research Institute.

\section{ReFERENCES}

Ahyong, S.T.; Haug, J.T. and Haug, C. 2014. Stomatopoda. p. 185-189. In: J.W. Martin, J. Olesen and J.T. Høeg (eds), Atlas of Crustacean Larvae. Baltimore, The Johns Hopkins, University Press.

Alikunhi, K.H. 1944. Final pelagic larva of Squilla hieroglyphica Kemp. Current Science, Bangalore, 13(9): 237-238.

Barber, P. and Boyce, S.L. 2006. Estimating diversity of IndoPacific coral reef stomatopods through DNA barcoding of stomatopod larvae. Proceedings of the Royal Society of London B, 273(1597): 2053-2061.

Bracken-Grissom, H.D.; Felder, D.L.; Vollmer, N.L.; Martin, J.W. and Crandall, K.A. 2012. Phylogenetics links monster larva to deep-sea shrimp. Ecology and Evolution, 2(10): 2367-2373.

Brandão, M.C.; Garcia, C.A.E. and Freire, A.S. 2015. Large-scale spatial variability of decapod and stomatopod larvae along the South Brazil Shelf. Continental ShelfResearch, 107: 11-23.

Brooks, W.H. 1886. Reports on the Stomatopoda collected by the H.M.S. "Challenger" during the years 1873-1876. Vol. 16, part 65, 16 pls. London, Eyre and Spothswoode, 116p.

Claus, C. 1871. Die Metamorphose der Squilliden. Nachrichten von der Königlichen Gesellschaft der Wissenschaften und der Georg-Augusts-Universität zu Göttingen, 169-180.

Crompton, D.W.T. and Nickol, B.B. 1985. Biology of the Acanthocephala. Cambridge, Cambridge University Press, $519 \mathrm{p}$.

Diaz, G.A. and Manning, R.B. 1998. The last pelagic stage and juvenile of Lysiosquilla scabricauda (Lamarck, 1818) (Crustacea, Stomatopoda). Bulletin of Marine Science, 63(2): 453-457.

Eiler, S.M.; Haug, C. and Haug, J.T. 2016. Detailed description of a giant polychelidan Eryoneicus-type larva with modern imaging techniques. Spixiana, 39(1): 39-60.

Feller, K.D.; Cronin, T.W.; Ahyong, S.T. and Porter, M.L. 2013. Morphological and molecular description of the late-stage larvae of Alima Leach, 1817 (Crustacea: Stomatopoda) from Lizard Island, Australia. Zootaxa, 3722(2): 22-32.

Foxon, G.E.H. 1932. Report on stomatopod larvae, Cumacea and Cladocera. Great Barrier Reef Expedition 1928-1929, Scientific Reports (British Museum (Natural History), 4(11): 375-398.

Gamô, S. 1979. Notes on a giant stomatopod larva taken southeast of Mindanao, Philippines (Crustacea). Science Reports of the Yokohama National University, sect, 2: 11-18.

Giesbrecht, W. 1910. Stomatopoden, Erster Theil. Fauna und Flora des Golfes von Neapel, Monographie, 33: 1-39.

Gohar, H. A. F. and Al-Kholy, A.A. 1957. The larval stages of three stomatopod Crustacea. Publications of the Marine Biological Station, Al-Ghardaqa, Red Sea, 9: 85-130. 
Greenwood, J.G. and Williams, B.G. 1984. Larval and early postlarval stages in the abbreviated development of Heterosquilla tricarinata (Claus, 1871) (Crustacea, Stomatopoda). Journal of Plankton Research, 6(4): 615-635.

Gurney, R. 1942. Larvae of Decapod Crustacea. London, Ray Society, 306p.

Gurney, R. 1946. Notes on Stomatopod Larvae. Proceedings of the Zoological Society of London, 116(1): 133-175.

Hamano, T. and Matsuura, S. 1987. Egg size, duration of incubation, and larval development of the Japanese mantis shrimp in the laboratory. Nippon Suisan Gakkaishi, 53(1): 23-39.

Hansen, H.J. 1926. The Stomatopoda of the Siboga Expedition. Siboga Expeditie 1899-1900, Monog. 18, 2 pls. Leiden, E.J. Brill, 48p.

Haug, C. and Haug, J.T. 2014. Defensive enrolment in mantis shrimp larvae (Malacostraca: Stomatopoda). Contributions to Zoology, 83(3): 185-194.

Haug, C.; Haug, J.T.; Waloszek, D.; Maas, A.; Frattigiani, R. and Liebau, S. 2009. New methods to document fossils from lithographic limestones of southern Germany and Lebanon. Palaeontologia Electronica, 12: 6T, 12p.

Haug, C.; Mayer, G.; Kutschera, V.; Waloszek, D.; Maas, A. and Haug, J.T. 2011. Imaging and documenting gammarideans. International Journal of Zoology, art. 380829, DOI $10.1155 / 2011 / 380829$

Haug, J.T.; Rudolf, N.R.; Wagner, P.; Gundi, P.T.; Fetzer, L.-L. and Haug, C. 2016. An intermetamorphic larval stage of a mantis shrimp and its contribution to the 'missing-element problem' of stomatopod raptorial appendages. Annual Research \& Review in Biology, 10(3): 1-19.

Haug, C.; Sallam, W.S.; Maas, A.; Waloszek, D.; Kutschera, V. and Haug, J.T. 2012. Tagmatization in Stomatopoda - reconsidering functional units of modern-day mantis shrimps (Verunipeltata, Hoplocarida) and implications for the interpretation of fossils. Frontiers in Zoology, 9: art. 31.

Johnson, M.W. 1971. The phyllosoma larvae of slipper lobsters from the Hawaiian Islands and adjacent areas (Decapoda, Scyllaridae). Crustaceana, 20(1): 77-103.

Kennedy, C.R. 2006. Ecology of the Acanthocephala. Cambridge, Cambridge University Press, 260p.

Lewis, J.B. 1951. The phyllosoma larvae of the spiny lobster Panulirus argus. Bulletin of Marine Science, 1(2): 89-103.

Manning, R.B. and Provenzano, A.J. 1963. Studies on development of stomatopod Crustacea I. Early larval stages of Gonodactylus oerstedii Hansen. Bulletin of Marine Science, 13(3): 467-487.

Martin, J.W. 2014. Polychelida. p. 279-282. In: J.W. Martin, J. Olesen and J.T. Høeg (eds), Atlas of Crustacean Larvae. Baltimore, The Johns Hopkins University Press.
Michel, A. 1968. Dérive des larves de Stomatopodes de l'est de l'Ocean Indien. Cahiers de l'ORSTOM, série Océanographique, 6(1): 13-39.

Michel, A. and Manning, R.B. 1972. The pelagic larvae of Chorisquilla tuberculata (Borradaile, 1907) (Stomatopoda). Crustaceana, 22(2): 113-126.

Morgan, S.G. and Goy, J.G. 1987. Reproduction and larval development of the mantis shrimp Gonodactylus bredini (Crustacea: Stomatopoda) maintained in the laboratory. Journal of Crustacean Biology, 7(4): 595-618.

Morgan, S.G. and Provenzano, A.J. 1979. Development of pelagic larvae and postlarva of Squilla empusa (Crustacea, Stomatopoda) with an assessment of larval characters within the Squillidae. Fishery Bulletin, 77(1): 61-90.

Palero, F.; Clark, P.F. and Guerao, G. 2014. Achelata. p. 272278. In: J.W. Martin, J. Olesen and J.T. Høeg (eds), Atlas of Crustacean Larvae. Baltimore, The Johns Hopkins University Press.

Provenzano, A.J., and Manning, R.B. 1978. Studies on development of stomatopod Crustacea II. The later larval stages of Gonodactylus oerstedii Hansen reared in the laboratory. Bulletin of Marine Science, 28(2): 297-315.

Pyne, R.R. 1972. Larval development and behaviour of the mantis shrimp, Squilla armata Milne Edwards (Crustacea: Stomatopoda). Journal of the Royal Society of New Zealand, 2(2): 121-146.

Shanbhogue, S.L. 1975. Descriptions of stomatopod larvae from the Arabian Sea with a list of stomatopod larvae and adults from the Indian Ocean and a key for their identification Part 1. Journal of the Marine Biological Association of India, 17(2): 196-238.

Tang, W.K. 2009. Distribution, seasonality and species identification of larval Stomatopoda in Hong Kong waters. The University of Hong Kong, Hong Kong, China. Master Dissertation. 212p. [Unpublished].

Tang, R.W.; Yau, C. and Ng, W.C. 2010. Identification of stomatopod larvae (Crustacea: Stomatopoda) from Hong Kong waters using DNA barcodes. Molecular Ecology Resources, 10(3): 439-448.

Torres, A.P.; Palero, F.; Santos, A.; Abelló, P.; Blanco, E.; Boné, A. and Guerao, G. 2014. Larval stages of the deep-sea lobster Polycheles typhlops (Decapoda, Polychelida) identified by DNA analysis: morphology, systematic, distribution and ecology. Helgoland Marine Research, 68(3): 379-397.

Townsley, S.J. 1953. Adult and larval stomatopod crustaceans occurring in Hawaiian waters. Pacific Science, 7(4): 399-437.

Veena, S. and Kaladharan, P. 2010. Mantis shrimp larvae from the inshore waters of Visakhapatnam, India. Marine Biodiversity Records, 3: art. e126.

Williamson, D.I. and Rice, A.L. 1996. Larval evolution in the Crustacea. Crustaceana, 69(3): 267-287. 